\title{
Theory of Planned Behavior sebagai Upaya Peningkatan Kepatuhan pada Klien Diabetes Melitus
}

\author{
Theory of Planned Behavior as Efforts to Increase Complience in Diabetes \\ Mellitus Clients
}

\author{
Ni Nyoman Wahyu Lestarina \\ STIKES Katolik St. Vincentius a Paulo Surabaya \\ (wahyulestarina@yahoo.co.id)
}

\begin{abstract}
ABSTRAK
Diabetes Melitus (DM) merupakan penyakit yang sering menimbulkan komplikasi sehingga memerlukan perawatan dan pengobatan jangka panjang. Hasil studi pendahuluan didapatkan dari 10 responden sebanyak $50 \%$ klien sulit mematuhi diet, $60 \%$ merasa jenuh dan bosan terhadap pengobatan DM, 10\% klien yang menjalani olahraga secara teratur, serta 50\% klien mengatakan takut akan komplikasi DM. Tujuan dari penelitian ini adalah mengembangkan model peningkatan kepatuhan berbasis Theory of Planned Behavior klien DM tipe 2 di wilayah kerja Puskesmas Gundih Surabaya. Desain penelitian studi ini adalah explanative observasional dengan pendekatan cross sectional. Populasi dalam penelitan ini adalah klien DM tipe 2 yang tinggal di wilayah kerja Puskesmas Gundih Surabaya dengan jumlah sampel 100 responden. Teknik pengambilan sampel menggunakan quota sampling. Variabel dalam penelitian ini adalah usia, jenis kelamin, pendidikan, pengetahuan, sikap, norma subjektif, persepsi terhadap pengendalian, niat, kepatuhan tatalaksana DM dan kadar gula darah. Instrumen yang digunakan adalah kuesioner. Hasil penelitian dianalisis menggunakan PLS (Partial Least Square) kemudian didapatkan isu strategis dan dilakukan Focus Group Discussion (FGD). Hasil penelitian menunjukkan bahwa faktor latar belakang mempunyai pengaruh terhadap sikap, norma subjektif dan percieved behavior control dengan nilai t-statistik sebesar 11,356, sikap, norma subjektif dan percieved behavior control mempunyai pengaruh terhadap intensi dengan nilai t-statistik 13,935, intensi mempunyai pengaruh terhadap kepatuhan dengan nilai t-statistik 7,80 dan kepatuhan mempunyai pengaruh terhadap kadar gula darah dengan nilai t-statistik 4,592. Model pengembangan kepatuhan tatalaksana pasien DM mempertimbangkan faktor intensi, sikap, norma subjektif dan percieved behavioral.
\end{abstract}

Kata kunci : Kepatuhan, theory of planned behavior, diabetes mellitus

\section{ABSTRACT}

Diabetes mellitus (DM) is a disease that often caused complications that require care and long-term treatment. Preliminary study obtained from 10 respondents, $50 \%$ of clients difficult to comply with diet, $60 \%$ felt tired and bored to the treatment of diabetes, $10 \%$ of clients have regular exercise, and $50 \%$ of clients said that fear of complications of DM. The purpose of this study is developing model improved compliance based Theory of Planned Behavior in client type 2 Diabetes Mellitus on Community Health Centre Gundih Surabaya. This study used explanative observational with cross sectional approach. The population in this research is type 2 DM client who lives in community health centre Gundih Surabaya. Sampling technique used purposive sampling and 100 patient obtained as a sample. The variables in this study were age, sex, education, knowledge, attitudes, subjective norms, perceptions of control, intention, compliance management of diabetes and blood sugar levels. Data collection was using questionnaire and analyzed using PLS (Partial Least Square). Statistic analysis result shows there is significant relationship between attitude, subjective norm and percieved behavioral control toward intention with t-value 13,935. There is significant relationship between intention with compliance with t-value 7,80.There is significant relationship between compliance and blood sugar level with t-value 4,592. Theory of Planned Behavior (TPB) stated that behavior could effectd by intention, attitude, subjctive norm and percieved behavioral control.

Keywords : Compliance, theory of planned behavior, diabetes mellitus 


\section{PENDAHULUAN}

Diabetes Melitus (DM) merupakan penyakit metabolik yang terjadi akibat kelainan sekresi atau kerja insulin dengan tanda peningkatan kadar glukosa darah. ${ }^{1}$ Diabetes sering menimbulkan komplikasi sehingga memerlukan dukungan edukasi berkaitan dengan perawatan dan pengobatan jangka panjang klien DM. Pengelolaan diabetes dapat memberikan hasil maksimal apabila dibarengi dengan kepatuhan klien terhadap terapi yang dianjurkan oleh petugas kesehatan. Keberhasilan pengelolaan penyakit ditentukan dari perilaku patuh penderita DM terhadap tatalaksana penyakit tersebut. Dengan kepatuhan yang baik, pengobatan dapat terlaksana secara optimal dan kualitas kesehatan dapat dirasakan oleh pasien.

Prevalensi diabetes di Jawa Timur menurut data Riset Kesehatan Dasar (Riskesdas) tahun 2013 sebesar $2,1 \%$ terjadi pada usia $>16$ tahun dan meningkat seiring bertambahnya umur. ${ }^{3}$ Hasil studi pendahuluan yang dilakukan di Puskesmas Gundih dengan cara wawancara pada tanggal 5 Januari 2016, didapatkan dari 10 responden sebanyak 50\% klien sulit mematuhi diet, $60 \%$ merasa jenuh dan bosan terhadap pengobatan DM, 10\% klien yang menjalani olahraga secara teratur, serta $50 \%$ klien mengatakan takut, cemas akan komplikasi DM. Menurut hasil penelitian Lestari di RSUP Fatmawati Jakarta didapatkan 44\% klien tidak patuh terhadap tata laksana diet. ${ }^{4}$

Theory of Planned Behavior menurut Ajzen menyatakan bahwa seseorang dapat melakukan atau tidak melakukan suatu perilaku tergantung dari niat orang tersebut. ${ }^{6}$ Niat merupakan hal-hal yang dapat menjelaskan faktor-faktor motivasi serta berdampak kuat pada tingkah laku. ${ }^{7}$ Niat melakukan suatu perilaku ditunjang dengan keyakinan seseorang pada perilaku tersebut. Keyakinan diperoleh dengan pemberian pengetahuan, keterampilan dan pengalaman untuk melaksanakan prilaku tersebut. Niat yang kuat dari seorang penderita DM, akan meningkatkan kepatuhan klien dalam menjalankan tatalaksana penyakitnya.

Klien DM cenderung memiliki masalah kepatuhan dalam pengobatan sehingga berisiko timbul komplikasi. Kebanyakan penderita DM tidak akan minum obat serta memeriksakan gula darahnya apabila tidak ada keluhan. Semakin buruk kontrol mereka terhadap ketidakpatuhan, semakin mudah klien terkena komplikasi. ${ }^{8}$ Komplikasi akut penyakit DM antara lain hipoglikemia, ketoasidosis, dan koma. Komplikasi kronis penyakit DM adalah kerusakan saraf, penyakit jantung, gangguan hepar, penyakit ginjal, gangguan pencernaan, dan rentan terhadap infeksi. ${ }^{9}$

Hasil penelitian yang dilakukan oleh Tol, tim kesehatan harus memperkenalkan "self empowerment" untuk mengatur penyakit kronis dengan cara memberikan informasi dan edukasi. ${ }^{10}$ Berdasarkan hal tersebut maka perlu adanya penelitian pengembangan model untuk peningkatan kepatuhan tatalaksana penderita DM agar keberhasilan terapi dapat tercapai.

\section{BAHAN DAN METODE}

Desain yang digunakan dalam penelitian ini adalah explanative observasional dengan pendekatan yang digunakan pada penelitian ini adalah cross sectional. Jumlah sampel dalam penelitian ini sebanyak 100 orang klien DM tipe 2 yang tinggal di wilayah kerja Puskesmas Gundih Surabaya dengan kriteria inklusi yaitu: klien

Tabel 1. Karakteristik Responden

\begin{tabular}{lcc}
\hline \multicolumn{1}{c}{ Karakteristik } & $\mathbf{n = 1 0 0}$ & $\mathbf{\%}$ \\
\hline Usia (tahun) & & \\
$36-45$ & 4 & 4 \\
$46-55$ & 25 & 25 \\
$56-65$ & 45 & 45 \\
$>65$ & 26 & 26 \\
Jenis kelamin & & \\
$\quad$ Perempuan & 74 & 74 \\
$\quad$ Laki-laki & 26 & 26 \\
Tingkat pendidikan & & \\
Tidak sekolah & 3 & 3 \\
SD & 27 & 27 \\
SMP & 30 & 30 \\
SMA & 35 & 35 \\
PT & 5 & 5 \\
Tingkat pengetahuan & & \\
Kurang & 15 & 15 \\
Cukup & 41 & 41 \\
Baik & 44 & 44 \\
Lama menderita DM (tahun) & & \\
$1-3$ & 45 & 45 \\
$4-6$ & 18 & 18 \\
7 - 9 & 12 & 12 \\
$10-12$ & 10 & 10 \\
$13-15$ & 2 & 2 \\
$>15$ & 13 & 13 \\
\hline
\end{tabular}


Tabel 2. Tabulasi Silang Sikap, Norma Subjektif dan PBC terhadap Intensi

\begin{tabular}{|c|c|c|c|c|c|c|}
\hline \multirow{3}{*}{ Variabel } & \multicolumn{4}{|c|}{ Intensi } & \multirow{2}{*}{\multicolumn{2}{|c|}{ Total }} \\
\hline & \multicolumn{2}{|c|}{ Baik } & \multicolumn{2}{|c|}{ Kurang } & & \\
\hline & $n=38$ & $\%$ & $n=62$ & $\%$ & $n=100$ & $\%$ \\
\hline \multicolumn{7}{|l|}{ Sikap } \\
\hline Positif & 26 & 26 & 22 & 22 & 48 & 48 \\
\hline \multirow[t]{2}{*}{ Negatif } & 12 & 12 & 40 & 40 & 52 & 52 \\
\hline & $t=1,527$ & \multicolumn{3}{|c|}{ Path coef $=0,172$} & & \\
\hline \multicolumn{7}{|l|}{ Norma Subjektif } \\
\hline Baik & 33 & 33 & 24 & 24 & 57 & 57 \\
\hline \multirow[t]{2}{*}{ Kurang } & 5 & 5 & 38 & 38 & 43 & 43 \\
\hline & $\mathrm{t}=4,497$ & \multicolumn{3}{|c|}{ Path coef $=0,459$} & & \\
\hline \multicolumn{7}{|c|}{ Percieved Behavioral Control } \\
\hline Baik & 27 & 27 & 14 & 14 & 41 & 41 \\
\hline \multirow[t]{2}{*}{ Kurang } & 11 & 11 & 48 & 48 & 59 & 59 \\
\hline & $\mathrm{t}=1,719$ & \multicolumn{3}{|c|}{ Path coef $=0,232$} & & \\
\hline
\end{tabular}

DM yang mendapat Obat Anti Diabetes (OAD), usia $>40$ tahun, menderita $D M \geq 1$ tahun. Teknik pengambilan sampel menggunakan teknik purposive sampling. Variabel dalam penelitian ini adalah usia, jenis kelamin, pendidikan, pengetahuan, sikap, norma subjektif, persepsi terhadap pengendalian, niat, kepatuhan tatalaksana DM dan kadar gula darah. Instrumen yang dipergunakan untuk mengetahui pengetahuan, sikap, norma subyektif, persepsi terhadap pengendalian, intensi dan kepatuhan menggunakan kuesioner. Pengukuran gula darah dilakukan dengan mengambil sampel darah puasa klien. Teknik analisis yang digunakan adalah model persamaan struktural berbasis variance atau component based yang disebut PLS (Partial Least Square). Evaluasi model terdiri dari dua bagian evaluasi, yaitu evaluasi model pengukuran dan evaluasi struktural.

\section{HASIL}

Hasil penelitian didapatkan sebagian besar penderita DM berusia 56-65 tahun sebanyak 45\%, diderita oleh perempuan sebanyak $74 \%$ dan menderita DM 1-3 tahun sebanyak 45\% serta pengetahuan responden berada pada kategori baik sebanyak 44\% (Tabel 1) .

Responden mempunyai hasil intensi dalam tatalaksana berada pada kategori kurang (62\%). Intensi yang kurang dipengaruhi oleh sikap negatif (40\%), norma subjektif kurang (38\%) dan percieved behavioural control yang kurang (48\%).
Intensi responden dalam menjaga makanan yang dikonsumsi dan olahraga teratur masih kurang. Sikap dan percieved behavioural control tidak signifikan terhadap intensi. Berdasarkan hasil uji statistik PLS didapatkan nilai $\mathrm{t}<1,96$. Norma subjektif signifikan terhadap intensi. Berdasarkan hasil uji statistik PLS didapatkan nilai $t>1,96$ (Tabel 2).

Hasil penelitian didapatkan tingkat kepatuhan responden dalam tatalaksana DM berada pada kategori cukup (42\%). Kepatuhan kurang cenderung dipengaruhi oleh intensi yang kurang. Hasil tersebut menginformasikan bahwa intensi terbukti berpengaruh terhadap kepatuhan tatalaksana DM. Berdasarkan hasil uji statistik PLS didapatkan nilai koefisien jalur 0,603 dengan t statistik : 7,771 yang berarti signifikan (Tabel 3 ).

Hasil penelitian menunjukkan bahwa sebanyak $72 \%$ responden mempunyai kadar gula darah yang buruk. Kadar gula darah yang buruk cenderung dipengaruhi oleh kepatuhan yang kurang. Berdasarkan hasil uji statistik PLS didapatkan nilai koefisien jalur sebesar -0,409 dengan nilai $t$ statistik : 4,470 yang berarti semakin baik kepatuhan, kadar gula darah semakin menurun (Tabel 4).

Tabel 5 menunjukkan bahwa besarnya koefisien parameter background factor terhadap faktor utama nilainya 0,605 yang berarti terdapat pengaruh positif dengan nilai $t$ statistik sebesar 11,807 . Besarnya koefisien parameter faktor utama terhadap intensi nilainya 0,734 yang berarti 
Tabel 3. Tabulasi Silang Kepatuhan dan Intensi

\begin{tabular}{|c|c|c|c|c|c|c|}
\hline \multirow{3}{*}{ Variabel } & \multicolumn{4}{|c|}{ Intensi } & \multirow{2}{*}{\multicolumn{2}{|c|}{ Total }} \\
\hline & \multicolumn{2}{|c|}{ Baik } & \multicolumn{2}{|c|}{ Kurang } & & \\
\hline & $\mathbf{n}=\mathbf{3 8}$ & $\%$ & $n=62$ & $\%$ & $\mathrm{n}=\mathbf{1 0 0}$ & $\%$ \\
\hline \multicolumn{7}{|l|}{ Kepatuhan } \\
\hline Baik & 20 & 20 & 14 & 14 & 34 & 34 \\
\hline Cukup & 16 & 16 & 26 & 26 & 42 & 42 \\
\hline Kurang & 2 & 2 & 22 & 22 & 24 & 24 \\
\hline \multicolumn{7}{|c|}{$\mathrm{t}=7,771 ;$ Path coef $=0,603$} \\
\hline
\end{tabular}

Tabel 4. Tabulasi Silang Kepatuhan dan Kadar Gula Darah

\begin{tabular}{|c|c|c|c|c|c|c|}
\hline \multirow{3}{*}{ Variabel } & \multicolumn{4}{|c|}{ Kadar GDP } & \multirow{2}{*}{\multicolumn{2}{|c|}{ Total }} \\
\hline & \multicolumn{2}{|c|}{ Baik } & \multicolumn{2}{|c|}{ Kurang } & & \\
\hline & $n=38$ & $\%$ & $n=62$ & $\%$ & $n=100$ & $\%$ \\
\hline \multicolumn{7}{|l|}{ Kepatuhan } \\
\hline Baik & 16 & 16 & 18 & 18 & 34 & 34 \\
\hline Cukup & 11 & 11 & 31 & 31 & 42 & 42 \\
\hline \multirow[t]{2}{*}{ Kurang } & 1 & 1 & 23 & 23 & 24 & 24 \\
\hline & $\mathrm{t}=4$ & $P c$ & $=-0,40$ & & & \\
\hline
\end{tabular}

terdapat pengaruh positif dengan nilai $t$ statistik sebesar 13,442. Besarnya koefisien intensi terhadap kepatuhan nilainya 0,603 yang berarti terdapat pengaruh positif dengan nilai $\mathrm{t}$ statistik sebesar 7,447. Besarnya koefisien parameter kepatuhan terhadap kadar GDP nilainya -0,409 yang berarti terdapat pengaruh negatif dengan nilai $\mathrm{t}$ statistik sebesar 4,378. Isu strategis yang didapatkan dari analisis PLS yaitu background faktor, faktor utama, intensi dan kepatuhan.

\section{PEMBAHASAN}

Hasil penelitian didapatkan bahwa jenis kelamin dan pengetahuan mempunyai pengaruh yang signifikan terhadap faktor utama (sikap, norma subjektif dan percieved behavioral control). Besarnya koefisien parameter background factor terhadap faktor utama nilainya 0,602 yang berarti terdapat pengaruh positif dengan nilai $t$ statistik sebesar 11,356. Jenis kelamin merupakan salah satu faktor genetik yang mempengaruhi seseorang untuk bersikap dan berperilaku, selain dari faktor lingkungan. Perempuan lebih baik daripada remaja laki-laki dalam perilaku hidup sehat. Hal ini dapat dipengaruhi oleh faktor-faktor lain, seperti faktor lingkungan sekitarnya, jika lingkungan sekitarnya senantiasa menerapkan perilaku hidup sehat dapat menimbulkan sikap yang positif untuk berperilaku hidup sehat. ${ }^{11}$ Penelitian Ajzen mengatakan bahwa seseorang tumbuh dan berkembang dalam lingkungan yang berbeda-beda, hal ini yang menyebabkan orang tersebut dapat memperoleh informasi yang berbeda-beda pula mengenai suatu permasalahan. Informasi tersebut dapat menjadi dasar dari keyakinan mereka mengenai konsekuensi dari perilaku, mengenai harapan normatif dari pihak lain yang penting serta berbagai hambatan yang mencegah untuk melakukan suatu perilaku. ${ }^{6}$

Berdasarkan hasil penelitian sikap, norma subjektif dan percieved behavioral control yang kurang mempunyai intensi yang kurang dengan besarnya koefisien parameter 0,734 yang berarti terdapat pengaruh positif. Menurut Ajzen, sikap terhadap perilaku merupakan salah satu faktor penentu terbentuknya intensi. Sikap terhadap perilaku didefinisikan Ajzen sebagai derajat penilaian positif atau negatif individu terhadap perilaku tertentu. Sikap terhadap perilaku ditentukan oleh evaluasi individu mengenai hasil yang berhubungan dengan perilaku dan dengan kekuatan hubungan dari kedua hal tersebut. Semakin individu memiliki evaluasi bahwa suatu perilaku akan menghasilkan konsekuensi positif maka individu akan cenderung bersikap favorable terhadap perilaku tersebut. Sikap terhadap perilaku tersebut yang akan mempengaruhi intensi seseorang dalam 
Tabel 5. Hasil Uji Hipotesis

\begin{tabular}{lcc}
\hline \multicolumn{1}{c}{ Variabel } & $\begin{array}{c}\text { Koefisien } \\
\text { parameter }\end{array}$ & t-statistik \\
\hline $\begin{array}{l}\text { Pengaruh background } \\
\text { factor terhadap faktor } \\
\text { utama }\end{array}$ & 0,602 & 11,356 \\
$\begin{array}{l}\text { Pengaruh faktor utama } \\
\text { terhadap intensi }\end{array}$ & 0,734 & 13,935 \\
$\begin{array}{l}\text { Pengaruh intensi terhadap } \\
\text { kepatuhan }\end{array}$ & 0,603 & 7,380 \\
$\begin{array}{l}\text { Pengaruh Kepatuhan } \\
\text { terhadap kadar GDP }\end{array}$ & $-0,409$ & 4,592 \\
\hline
\end{tabular}

memunculkan sebuah perilaku. ${ }^{5} \mathrm{Hal}$ ini diperkuat dengan hasil penelitian Maradona menunjukkan terdapat hubungan positif antara sikap dengan intensi kepatuhan pelanggan. ${ }^{12}$

Norma subjektif merupakan persepsi seseorang mengenai tekanan sosial untuk melakukan atau tidak melakukan perilaku. ${ }^{13}$ Apabila individu merasa bahwa perilaku tersebut bukan ditentukan oleh orang lain, maka dia akan mengabaikan pandangan orang tentang perilaku yang akan dilakukannya. Norma subyektif berupa keyakinan individu untuk mematuhi arahan atau anjuran orang di sekitarnya untuk turut dalam melaksanakan tatalaksana DM. ${ }^{14}$

Hasil penelitian Adi menjelaskan bahwa norma subjektif terbukti mempengaruhi intensi pemeriksaan dini kanker serviks dan pengaruh norma subjektif sendiri lebih besar pengaruhnya dibandingkan dengan sikap dalam menentukan intensi pemeriksaan deteksi dini kanker serviks. ${ }^{15}$ Penelitian Maradona juga menunjukkan hal yang serupa bahwa terdapat hubungan positif antara norma subjektif dengan intensi kepatuhan pelanggan. $^{12}$

PBC yaitu persepsi individu mengenai mudah atau tidaknya individu untuk melakukan perilaku dan diasumsikan merupakan refleksi dari pengalaman yang telah terjadi sebelumnya juga hambatan-hambatan yang diantisipasi. ${ }^{5}$ Semakin banyak faktor pendukung dan sedikit faktor penghambat yang individu rasakan untuk dapat melakukan suatu perilaku, maka lebih besar kontrol yang mereka rasakan atas perilaku tersebut dan begitu juga sebaliknya. Persepsi tersebut ditentukan oleh keyakinan (beliefs) seseorang, yang disebut control beliefs, untuk mengendalikan faktor yang menghambat ataupun yang mendorong munculnya perilaku. ${ }^{6}$ Keyakinan-keyakinan ini dapat diakibatkan oleh pengalaman masa lalu dengan tingkah laku tersebut, tetapi juga dapat dipengaruhi oleh informasi yang tidak langsung akan tingkah laku tersebut yang diperoleh dengan mengobservasi pengalaman orang yang dikenal atau teman, sedangkan faktor yang dikontrol adalah faktor internal dan faktor eksternal.

Faktor internal seperti keahlian, kemampuan, informasi, dan emosi, dan lain-lain, sedangkan faktor eksternal yaitu faktor situasi atau faktor lingkungan. Penelitian Tsalits didapatkan informasi bahwa kontrol diri dalam perilaku merokok mempunyai hubungan yang positif terhadap intensi berhenti merokok pada remaja SLTA dengan nilai efektif mencapai $60,4 \%$. Hal ini berarti kontrol diri dalam perilaku merokok cukup memberikan pengaruh untuk menumbuhkan intensi berhenti merokok. ${ }^{16}$

Berdasarkan hasil penelitian, besarnya koefisien intensi terhadap kepatuhan nilainya 0,603 yang berarti intensi mempunyai pengaruh terhadap kepatuhan tatalaksana, dengan nilai t statistik sebesar 7,380. Perilaku karena pilihan bebas (volutional behavior) dipengaruhi oleh intensi atau niat, dan kontrol aktual individu untuk menampilkan atau tidak menampilkan perilaku tersebut. Dalam kaitannya dengan kepatuhan tatalaksana DM, intensi kepatuhan menjalankan tatalaksana DM ditunjukkan pada motivasi individu menampilkan perilaku kepatuhan tersebut, yang menunjuk seberapa besar individu ingin melakukan suatu perilaku. ${ }^{5}$ Suatu perilaku dapat diubah dengan memodifikasi sistem keyakinan dominan yang mendasari (sikap, norma subjektif dan percieved behavioral control) sehingga memunculkan niat untuk merubah perilaku.

Theory of planned behavior menyatakan bahwa intensi merupakan faktor langsung dari tingkah laku maka dapat disebutkan bahwa tingkah laku individu tertentu akan konsisten dengan intensinya terhadap tingkah laku tersebut. Jika ada intensi untuk bertingkah laku tertentu, maka seseorang akan melakukan tingkah laku tersebut. ${ }^{13} \mathrm{Hal}$ ini diperkuat dengan hasil penelitian dari Suad- 
nyani yang mengatakan bahwa intensi berhubungan dengan kepatuhan perawat dalam melakukan pencegahan VAP. ${ }^{17}$

Berdasarkan hasil uji statistik didapatkan besarnya koefisien parameter kepatuhan terhadap kadar gula darah puasa nilainya -0,409 dengan nilai $t$ statistik sebesar 4,592 yang berarti ada pengaruh kepatuhan tatalaksana dengan kadar gula darah. Semakin tinggi tingkat kepatuhan kadar gula darah semakin baik. Peningkatan kualitas hidup pasien DM dipengaruhi oleh keberhasilan tatalaksana. Kurang optimalnya hasil pengobatan pada umumnya disebabkan oleh ketidakpatuhan pasien, ketidaktepatan peresepan, dan ketidaktepatan monitoring. Ketidakpatuhan pasien meningkatkan risiko komplikasi dan bertambah parahnya penyakit yang diderita. ${ }^{18}$

Keberhasilan terapi dapat dilihat dari adanya penurunan kadar gula darah puasa. Hasil penelitian Rahmawati \& Mutmaimah, dalam penelitiannya menunjukkan bahwa keberhasilan terapi dipengaruhi oleh kepatuhan penggunaan obat antihipertensi sebesar $18,03 \% .{ }^{19}$ Banyak faktor yang mempengaruhi ketidakpatuhan diantaranya tidak tahu mengenai penyakit dan penatalaksanaannya, kurangnya komunikasi dengan petugas kesehatan, ketidakmampuan ekonomi, serta kompleksitas regimen terapi. ${ }^{20}$

\section{KESIMPULAN DAN SARAN}

Kepatuhan dalam tatalaksana dapat dipengaruhi oleh jenis kelamin, tingkat pengetahuan, sikap, norma subjektif, percieved behavioral control serta intensi. Melakukan pendampingan yang lebih intensif kepada pasien serta meningkatkan peran serta keluarga dalam peningkatan kepatuhan pasien DM dalam menjalankan tatalaksananya.

\section{DAFTAR PUSTAKA}

1. Soegondo S, Soegondo P, Subekti I, editors. Penatalaksanaan Diabetes Melitus Terpadu. 2nd ed. Jakarta: Balai Penerbit FKUI; 2015. $3 \mathrm{p}$.

2. Soelistijo SA, Novida H, Rudijanto A, Soewondo P, Suastika K, Manaf A, et al. Konsensus Pengelolaan dan Pencegahan Diabetes Melitus Tipe 2 di Indonesia 2015. Jakarta: PERKENI; 2015. 1-77 p.

3. Riskesdas. Riset Kesehatan Dasar 2013. Ja- karta; 2013.

4. Lestari TS. Hubungan Psikososial dengan Kepatuhan Diet Pasien Diabetes Melitus Tipe 2 Rawat Jalan di RSUP Fatmawati [Skripsi]. Depok : Universitas Indonesia; 2012.

5. Ajzen I. Attitudes, Personality, and Behavior. 2nd ed. Berkshire: Open University Press; 2005.

6. Fishbein M, Ajzen I. Predicting and Changing Behavior: The Reasoned Action Approach. New York: Psychology Press; 2010.

7. Thomas A. Santoso. Kemandirian Aktivitas Makan, Mandi dan Berpakaian pada Penderita Stroke 6-24 Bulan Pasca Okupasi Terapi [Skripsi]. Semarang : Universitas Diponegoro; 2003.

8. Jimmy B, Jose J. Patient Medication Adherence: Measures in Daily Practice. Oman Med J. 2011;26(3):155-9.

9. Nolan CJ, Damm P, Prentki M. Type 2 Diabetes Across Generations: from Pathophysiology to Prevention and Management. Lancet. Elsevier Ltd; 2011 Jul;378(9786):169-81.

10. Kapoor G, Mathur K. An analysis of Diabetes Empowerment and Distress in Patients of Diabetes Mellitus Type 2. Indian J Heal Wellbeing. 2015;6(8):757-62.

11. Andriadi W. Faktor-Faktor yang Berhubungan dengan Perilaku Hidup Bersih dan Sehat Anak Remaja Kelas VII dan VIII di SMP 258 Kelurahan Cibubur Jakarta Timur Tahun 2011. 2011.

12. Maradona. Hubungan Sikap Pelanggan, Norma Subjektif Pelanggan dan Kontrol Perilaku Pelanggan dengan Intensi Kepatuhan Pelanggan dalam Membayar Tagihan Jasa Telepon Rumah di Pt. Telkomunikasi Indonesia, Tbk Malang (Penerapan Teory Of Planned Behavior). Fakultas Psikologi UIN Maulana Malik Ibrahim Malang; 2009.

13. Fishbein M, Ajzen I. Belief, Attitude, Intention, and Behavior: An introduction to Theory and Research. Philippines: Addison-Wesley Publishing Company; 1975.

14. Ramayah T, Harun Z. Entrepreneurial Intention Among the Student of Universiti Sains Malaysia (USM)". , 1, 8-20. Int J Manag Entrep. 2005;1:8-20.

15. Adi TN. Wanita dan Deteksi Dini Kanker Ser- 
viks (Studi Korelasi antara Sikap dan Norma Subjektif dengan Intensi Wanita Dewasa dalam Pemeriksaan Deteksi Dini Kanker Serviks). Acta diurna. 2011;7(2):15-27.

16. Tsalits LH. Hubungan Dukungan Teman Sebaya dan Kontrol Perilaku dalam Merokok dengan Intensi Berhenti Merokok Pada Remaja SLTA [Internet]. Universitas Muhammadiyah Surakarta; 2013. Available from: http:// eprints.ums.ac.id/29430/.

17. Suadnyani NK. Penerapan Theory of Planned Behavior Terhadap Perilaku Kepatuhan Perawat dalam Pencegahan VAP di ICU Rumah Sakit Katolik Surabaya [Internet]. Universitas Airlangga; 2017. Available from: http://repos- itory.unair.ac.id/id/eprint/66445.

18. Pratita N. Hubungan Dukungan Pasangan dan Health Locus of Control dengan Kepatuhan dalam Menjalani Proses Pengobatan Pada Penderita Diabetes Mellitus Tipe 2. J Ilm Mahasiswa, Univ Surabaya. 2012;1:1.

19. Rahmawati, Mutmaimah. Hubungan antara Kepatuhan Penggunaan Obat dan Keberhasilan Terapi Pada Pasien Hipertensi Di Rumah Sakit Daerah Surakarta. Pharmacon. 2010;11(2):51-6.

20. Bartels D. Adherence to Oral Therapy for Type 2 Diabetes: Opportunities for Enhancing Glycemic Control. J Am Acad Nurse Pract. 2004;16(1):8-16. 